\title{
Effect of Spacing on Yield Components and Yield of Chickpea (Cicer arietinumL.) at Assosa, Western Ethiopia
}

\author{
Melak Agajie \\ Ethiopian Biodiversity Institute (EBI) Assosa Biodiversity Center, Assosa, Ethiopia \\ Email address: \\ aempu12@gmail.com

\section{To cite this article:} \\ Melak Agajie. Effect of Spacing on Yield Components and Yield of Chickpea (Cicer arietinumL.) at Assosa, Western Ethiopia. Agriculture, \\ Forestry and Fisheries. Vol. 7, No. 2, 2018, pp. 39-51. doi: 10.11648/j.aff.20180702.11
}

Received: December 6, 2017; Accepted: April 26, 2018; Published: May 15, 2018

\begin{abstract}
A field experiment was conducted in Assosa District of western Ethiopia during 2013 cropping season to determine the effect of different inter row $(20,30,40,50 \mathrm{~cm})$ and intra row spacing $(5,10,15 \mathrm{~cm})$ on growth parameters, yield components and yield of Desi chickpea. The experimental design was randomized complete block design in factorial arrangement with three replications. There was highly significant $(\mathrm{P}<0.01)$ effect of both inter row and intra row spacing on days to $50 \%$ flowering, days to $90 \%$ maturity, number of seeds per pod, hundred seed weight. The $50 \mathrm{~cm}$ inter row spacing gave the highest number of seeds per pod (1.23) and hundred seed weight $(25.38 \mathrm{~g})$. Number of seeds per pod and hundred seed weight were significantly increased as the intra row spacing increased. The interaction effect of inter row and intra row spacing was significant on plant height, number of primary branches, number of pods per plant, above ground dry biomass, grain yield and harvest index. For all of the inter row spacing, the number of primary branches was increased as the intra row spacing increased. There was a progressive increase of number of pods per plant as the inter- and intra-row spacing increased while the highest above ground dry biomass $\left(10650.27 \mathrm{~kg} \mathrm{ha}^{-1}\right)$ was recorded at $20 \times 5 \mathrm{~cm}$ spacing. For all of the inter row spacing, the harvest index was increased as the intra row spacing increased. The $30 \mathrm{~cm}$ inter- by $10 \mathrm{~cm}$ intra- row spacing gave the highest grain yield $\left(1219 \mathrm{~kg} \mathrm{ha}^{-1}\right)$ while the lowest grain yield $\left(733 \mathrm{~kg} \mathrm{ha}^{-1}\right)$ was recorded from $50 \mathrm{~cm} \times 15 \mathrm{~cm}$ spacing which was statistically similar to the yield obtained from $40 \mathrm{~cm} \times 15 \mathrm{~cm}$ spacing. From this study it can be concluded that even if $20 \mathrm{~cm} \times 15 \mathrm{~cm}, 30 \mathrm{~cm} \times 15 \mathrm{~cm}, 30 \mathrm{~cm} \times 10 \mathrm{~cm}$ and $40 \mathrm{~cm} \times 5 \mathrm{~cm}$ spacing combinations showed statistical parity, $30 \mathrm{~cm} \times 10 \mathrm{~cm}$ or $30 \mathrm{~cm} \times 15 \mathrm{~cm}$ spacing can tentatively be recommended.
\end{abstract}

Keywords: 'Desi’ Type Chickpea, Inter-row Spacing, Intra-row Spacing

\section{Introduction}

Chickpea (Cicer arietinum L.)is a high-value crop that is adapted to deep black soils in the cool semi-arid areas of the tropics, sub-tropics as well as the temperate areas (e.g. Canada and Australia). The crop is originated in the present day southeastern Turkey and adjoining Syria where three wild annual species of Cicer viz., Cicer bijigum K. H. Rech, Cicer aerhinosperum P. H. Davis and Cicer reticulatum Ladare found ([83]). Ethiopia is a secondary center of diversity for chickpea [78].

Chickpea is the most important leguminous food grain in the diets of people in South and West Asia and northern Africa. It was grown on about 11.98 million hectares (ha) worldwide and its annual production was 10.89 million tones (t) during 2010 [31]. India alone accounts for $68.5 \%$ of the total chickpea growing area with $68.7 \%$ of the total world production. The other major chickpea producing countries are Pakistan, Iran, Australia, Turkey, Myanmar and Ethiopia. In Africa, Ethiopia stands first in area (213187 ha) and production $(284640 \mathrm{t})$, but third in productivity $(1335.2 \mathrm{~kg}$ $\mathrm{ha}^{-1}$ ) after Egypt and Sudan [31]. This clearly indicates the importance of chickpea in Ethiopian agriculture.

In Benishangul Gumuz Regional State, total area coverage and total production of chickpea crop is more than 377.38 ha of land and $234.46 \mathrm{t}$, respectively. Of the total area coverage Metekel Zone takes the lion share (208.47 ha) followed by Assosa Zone with 154.92 ha of chickpea land coverage [22].

Two types of chickpea are cultivated in the world: Desi and the Kabuli types. The Desi types have smaller seeds with angular appearance, sharp edges and varying colors. The Kabuli type produces large round seeds with white or pale 
cream or yellow color. Of the two groups, the Desi types are more widely cultivated in Ethiopia. Chick pea is generally grown in drought prone areas, and derives most of its water requirements from residual stored soil moisture rather than from rainfall, chickpea yields tend to trail those of cereals and other legumes cultivated in more favourable areas $[48,16]$.

Chickpea is one of the important cool season food legume crops of Ethiopia which is mainly grown in the central, northern and eastern highland areas of the country where the mean annual rainfall and altitude, respectively, range from 700-2000 $\mathrm{mm}$ and 1400-2300 meter above sea level [36]. The crop has a major role in the daily diet of the rural community and poor sectors of urban population and its straw is used for animal feed. Chickpea also fetches good price when sold in local market and hence generates cash to farmers. Moreover, the crop is being exported to Asia and Europe contributing positively to the country's foreign exchange earnings. For instance, in 2008 only Ethiopia had exported 39,993 metric $t$ of chickpea crop to different parts of the world [62]. Chickpea also improves the soil fertility through biological nitrogen fixation. Despite these facts, the yield of chickpea in Ethiopia is extremely low which can be attributed to factors such as water deficit, diseases, insects, weeds infestations and poor agronomic practices [83].

One of the main reasons of low yield of Carietinum is improper population. Too low and high plant population beyond a certain limit often adversely affects the crop yield. Number of plants per unit area influences plant size, yield components and ultimately the seed yield [14]. Moreover, plant spacing in the field is also very important to facilitate aeration and light penetration in to plant canopy for optimizing rate of photosynthesis. There is very little information available on the relative contribution of various plant spacing towards yield and yield components and also their interaction. It is reported that row spacing of $45 \mathrm{~cm}$ increased chickpea yield compared to 30 and $50 \mathrm{~cm}$ spacing while others indicated that row spacing had no significant effect on seed yield [74, 75].

Production and productivity of the crop is governed by environmental, genotypic trait of the crop and crop management. Determining appropriate crop geometry is therefore one of the most important crop management activities which improves the performance and productivity of plants. Generally based on size of the seed, research results indicated that the recommended seed rate for chickpea in Ethiopia ranges from $60-140 \mathrm{~kg} \mathrm{ha}^{-1}$ [29]. The planting density of chickpea in Ethiopia is $30 \mathrm{~cm} \times 10 \mathrm{~cm}$ spacing regardless of variety and agro climatic conditions. Various studies indicated that chickpea varieties and population densities have significant effects on the growth as well as yield parameters.

Even though the crop has a number of potential uses, the productivity of the crop in Ethiopia is very low under farmer's field. This is possibly due to: lack of improved variety to different environmental conditions, poor agronomic practices such as inappropriate use of seeding rate/plant density and variety selection. In addition to this, limited work has been done on the interaction effects of various agronomic practices such as variety with spacing in the country. There is also no site and variety specific recommendation on the plant population density of chickpea cultivars in Ethiopia rather; there is blanket recommendation of $30 \times 10 \mathrm{~cm}$ spacing. Therefore, the objective of this study was to determine the effect of inter- and intra- row spacing on yield components and yield of chickpea.

\section{Materials and Methods}

\subsection{Description of the Study Area}

A field experiment was conducted in Benishangul Gumuz Regional State at Asossa Agricultural Research Centre $\left(10^{0}\right.$ $02^{\prime} 05^{\prime \prime} \mathrm{N}$ latitude; $34^{0} 34^{\prime} 09.9^{\prime \prime} \mathrm{E}$ longitude; $1580 \mathrm{~m}$ above sea level altitude) in the 2013 cropping season. The study area is situated west of Addis Ababa about $663 \mathrm{~km}$ distance. The area experiences a monomodal rainfall pattern and has annual total rainfall of about $1275 \mathrm{~mm}$. The rainy season occurs from May to October and the maximum rain is received in the months of July and August. The minimum and maximum temperatures are $16.75^{\circ} \mathrm{C}$ and $27.92^{\circ} \mathrm{C}$, respectively. The soil type of the area is Nitisols and is dark reddish brown to dark red in colour [9].

\subsection{Description of Variety Used for the Study}

The chickpea variety used in the experiment was an improved Desi type variety 'Naatolii'. It was released by DebreZeit Agricultural Research Center (DZARC) in 2007 [67]. Days to maturity of this variety is 136,100 seed weight of $31 \mathrm{~g}$ and yield 2.2-2.6 $\mathrm{t} \mathrm{ha}^{-1}$.

\subsection{Treatments and Experimental Design}

A factorial combination of 4 inter row spacing $(20,30,40$ and $50 \mathrm{~cm})$ and 3 intra row spacing $(5,10$ and $15 \mathrm{~cm})$ was laid out in a randomized complete block design (RCBD)with three replications. These treatment combinations are;
1. $20 \mathrm{~cm} \times 5 \mathrm{~cm}$
2. $20 \mathrm{~cm} \times 10 \mathrm{~cm}$
3. $20 \mathrm{~cm} \times 15 \mathrm{~cm}$
4. $30 \mathrm{~cm} \times 5 \mathrm{~cm}$
5. $30 \mathrm{~cm} \times 10 \mathrm{~cm}$
6. $30 \mathrm{~cm} \times 15 \mathrm{~cm}$
7. $40 \mathrm{~cm} \times 5 \mathrm{~cm}$
8. $40 \mathrm{~cm} \times 10 \mathrm{~cm}$
9. $40 \mathrm{~cm} \times 15 \mathrm{~cm}$
$10.50 \mathrm{~cm} \times 5 \mathrm{~cm}$
$11.50 \mathrm{~cm} \times 10 \mathrm{~cm}$
$12.40 \mathrm{~cm} \times 15 \mathrm{~cm}$

\subsection{Management of the Experiment}

Land was prepared in August 2013 using tractor. The plot size was $3.6 \mathrm{~m}$ × $2.4 \mathrm{~m}$ and was leveled manually. The width between plots and between blocks was $0.7 \mathrm{~m}$ and $1.5 \mathrm{~m}$, respectively. As per the treatments there were 18, 12, 9 and 7 
rows for 20, 30, 40 and $50 \mathrm{~cm}$ inter-row spacing, respectively. The number of plants in each row was 48, 24 and 16 for intra row spacing of 5,10 and $15 \mathrm{~cm}$, respectively. The seeds were planted on September9, 2013 by placing a single seed per hole at a specific inter- and intra- row spacing. Gap filling was done to maintain an appropriate population 10days after planting. Weeding was done thrice during the growth of the crop. The first weeding and inter tillage activities were done 25 days after emergence, the second and the third weeding was practiced 30 days and 50 days after the first weeding, respectively. The outer most 3 rows on both sides of the $20 \mathrm{~cm}$ row spacing and the outer most 2 rows on both sides of the $30 \mathrm{~cm}$ row spacing served as border rows. In the $40 \mathrm{~cm}$ row spacing two rows from one side and one row from the other side served as border rows. In the $50 \mathrm{~cm}$ row spacing plots one row on both sides of the plot served as border rows. In intra row spacing of 5, 10 and $15 \mathrm{~cm}, 6,3$ and 2 plants on both ends of each row were the border plants, respectively. Thus, the net plot size was $2.4 \mathrm{~m} \times 1.8 \mathrm{~m}$.

\subsection{Soil Sampling and Analysis}

A soil sample was taken of $0-30 \mathrm{~cm}$ soil depth from 5 random spots of the experimental site with a zigzag method and a composite was made before planting. The composite sample was taken to Assosa Agricultural research center soil laboratory and analyzed for selected physic-chemical properties mainly textural analysis (percent sand, silt and clay), soil $\mathrm{pH}$, total nitrogen, organic matter content, available phosphorous $(\mathrm{P})$, exchangeable potassium $\left(\mathrm{K}^{+}\right)$and cation exchangeable capacity (CEC).

Analysis of organic matter content of the soil in a laboratory was determined by Walkley and wet oxidation method as described by Jackson (1958) and total nitrogen by Kjeldhal method as described by [14]. The $\mathrm{pH}$ of the soil was measured in water at soil to water ratio of $1: 2.5$, and cation exchange capacity was determined using Kjeldhal procedure as described by [73, 80]. Available phosphorous was determined according to the methods of Olsen and Dean and exchangeable potassium by flame photometer [70]. Soil texture analysis was performed by Bouyoucous hydrometer method [26].

\subsection{Data Collection}

\subsubsection{Phenological Data}

Days to emergence was recorded as the number of days from sowing to when $50 \%$ of the plants emerged in each plot. Similarly, number of days to flowering was recorded when $50 \%$ of the plants reached flowering stage. Days to maturity was recorded as the number of days from planting to the stage when $90 \%$ of the plant reached physiological maturity, i.e. when the plants and the pods turned pale yellow in colour based on visual observation.

\subsubsection{Growth, Yield Components and Yield}

Five plants in the net plot area were tagged just before flower initiation for taking observations on number of primary branches, plant height, and number of pods/plant, number of seeds/pod, aboveground dry biomass and harvest index at physiological maturity.

Number of primary branches was taken by counting the number of primary branches from the main stem at harvest. The aboveground biomass was sun dried until constant weight and its total and grain weight was recorded for calculating the harvest index. Number of pods per plant was recorded by counting the total number of pods from the tagged five plants and their average was taken as number of pods per plant at harvest. The twenty pods were randomly picked from the total pods as above and the seeds were counted to determine their number per pod.

The initial crop stand count was recorded by counting the total number of plants per net plot area 25 days after planting and final plant stand count was taken from net plot areas when the plants attained physiological maturity, the percent survival was calculated to determine the change in stand count due to competition and pest effect. One hundred grains from the bulk of harvested produce was counted from each plot and their weight was recorded as 100 -seed weight adjusted at $10 \%$ grain moisture content.

Grain yield from the net plot area of each plot was recorded by measuring the grain yield and adjusted at $10 \%$ grain moisture content using the formula.

Adjusted grain yield $=$ Recorded grain yield $\times 100-M / 100$ $\mathrm{D}$; where $\mathrm{M}$ is the measured moisture content and $\mathrm{D}$ is the designated moisture content $(10.0 \%)$.

\subsection{Statistical Data Analysis}

The various agronomic data collected were subjected to analysis of variance (ANOVA) appropriate to factorial arrangement in RCBD according to the Generalized Linear Model (GLM) of SAS and interpretations were made following the procedure described by [40]. Whenever the effects of the factors and interactions were found to be significant, the means were compared using the least significant differences (LSD) test at 5\% level of significance.

\section{Results and Discussion}

\subsection{Physico-Chemical Properties of Experimental Soil}

According to the laboratory analysis, the soil texture of the experimental area was clay (Table 1). The soil texture (proportion of sand, silt and clay in the soil) controls water contents, water intake rates, aeration, root penetration, and soil fertility. Though the best suited soils for chickpea are deep loam or silty clay loam soil, the texture of the experimental area was good [44], [70]. The $\mathrm{pH}$ of the soil was 6.0 , which is moderately acidic. It is indicated that plants grow well between $\mathrm{pH} 5.5$ andpH 8.5 [64]. Chickpea specifically grows well under the $\mathrm{pH}$ range of 6.0 to 8.0 [44].

The CEC of the soil of the experimental site was analyzed to be $22.6 \mathrm{cmol} / \mathrm{kg}$. According to the rating made by Landon (1984), this value lies in the lower range $(15-25 \mathrm{cmol} / \mathrm{kg})$, which means the soil, is not satisfactory for agricultural production. Further, the analysis indicated that the 
experimental soil had values of $0.168 \%, 2.460 \%, 2.480 \mathrm{ppm}$ and $0.1443 \mathrm{meq} 100 \mathrm{~g}^{-1}$ fortotal nitrogen, organic matter, available phosphorous and exchangeable potassium, respectively (Table 1). When the results of the analysis are compared with the broad ratings made by Metson A. J. all the values lie in the lower range for plant growth [63]. Though chickpea grows well on the marginal fertility areas, the deficiency of the soil for those major nutrient elements may cause yield reduction.

Table 1. Major physico-chemical properties of the experimental soil.

\begin{tabular}{lll}
\hline No. & Soil characters & Values \\
\hline 1 & pH (by 1: 2.5 soil water ratio) & 6.0 \\
2 & Organic matter $(\%)$ & 2.46 \\
3 & Total nitrogen $(\%)$ & 0.168 \\
4 & Available phosphorous $(\mathrm{ppm})$ & 2.48 \\
5 & Cation exchange capacity $(\mathrm{cmol}(+) / \mathrm{kg})$ & 22.6 \\
6 & Exchangeable potassium $(\mathrm{meq} / 100 \mathrm{~g} \mathrm{soil})$ & 0.1443 \\
7 & Soil texture: & \\
8 & Sand $(\%)$ & 30.5 \\
9 & Silt $(\%)$ & 9.1 \\
10 & Clay $(\%)$ & 60.4 \\
11 & Textural class & Clay \\
\hline
\end{tabular}

\subsection{Phenological Parameters}

\subsubsection{Days to 50\% Emergence}

There was no significant difference among inter- and intrarow spacing on days to $50 \%$ emergence as the plants emerged in about seven days after planting (Appendix Table 1). The adequate amount of soil moisture during planting might have triggered the seeds to germinate and emerge from the soil uniformly. This result was in agreement with a report where seed germination and establishment rate of faba bean were not affected by the sowing rate [7]. Similarly, It is also reported no significant effect of the inter- and the intra-row spacing as well as their interactions on days to $50 \%$ emergence on sesame [35].

\subsubsection{Days to 50\% Flowering}

The main effect of inter- and intra- row spacing was highly significant $(\mathrm{P}<0.01)$ while their interaction had no significant effect on days to $50 \%$ flowering (Appendix Table 1). Days to flowering was significantly decreased from 50.67 to 49.56 days as the inter-row spacing increased from $20 \mathrm{~cm}$ to $50 \mathrm{~cm}$ (Table 2). This might be due to the fact that wider inter row spacing had a better light interception as compared to the narrower row spacing resulting in less number of days to flower as chickpea needs direct sunlight coverage for its various physiological processes. Further, more nutritional area available in wider row spacing might have caused the crop to flower earlier than the closer spacing. On the other hand, in narrower inter row spacing due to competition for nutrients, moisture and space, the crop revealed delayed flowering. Besides moisture and nutrient utilization was more luxurious in the wider spaced inter rows as compared to the narrower row spacing. In agreement to this, the wide plant spacing of $50 \mathrm{~cm}$ reduced number of days to flower in broad bean than $40 \mathrm{~cm}$ plant spacing [32]. In contrast, it has been found that the denser plant population hastened days to flowering in lentil While, other found no significant effect of plant population on days to flowering in common bean [94], [1]. Similarly, in the wider intra row spacing, the plants attained $50 \%$ flowering earlier than the narrower spacing (Table 2). But works on safflower reported that inter- and intra- row spacing did not affect significantly the number of days to $50 \%$ flowering [69]. Therefore, it seemed that the influence of plant population on days to flower initiation varies from crop to crop as well as the prevailing environmental conditions under which the crops are grown.

Table 2. Main effects of inter- and intra-row spacing on days to 50\% emergence, days to $50 \%$ flowering and on days to physiological maturity of chickpea.

\begin{tabular}{llll}
\hline Treatment & Days to $\mathbf{5 0 \%}$ emergence & Days to 50\% flowering & Days to physiological maturity \\
\hline Inter row spacing $(\mathrm{cm})$ & & & $50.67^{\mathrm{a}}$ \\
20 & 7.11 & $50.33^{\mathrm{b}}$ & $104.78^{\mathrm{a}}$ \\
30 & 7.11 & $50.00^{\mathrm{c}}$ & $104.22^{\mathrm{b}}$ \\
40 & 7.11 & $49.56^{\mathrm{d}}$ & $104.00^{\mathrm{bc}}$ \\
50 & 7.11 & 0.291 & $103.78^{\mathrm{c}}$ \\
LSD $(0.05)$ & $\mathrm{NS}$ & & 0.358 \\
Intra row spacing & & $50.67^{\mathrm{a}}$ & $104.50^{\mathrm{a}}$ \\
$5 \mathrm{~cm}$ & 7.08 & $50.17^{\mathrm{b}}$ & $104.25^{\mathrm{a}}$ \\
$10 \mathrm{~cm}$ & 7.17 & $49.58^{\mathrm{c}}$ & $103.83^{\mathrm{b}}$ \\
$15 \mathrm{~cm}$ & 7.08 & 0.252 & 0.310 \\
LSD $(0.05)$ & $\mathrm{NS}$ & 0.59 & 0.35 \\
CV $(\%)$ & 4.8 & \\
\hline
\end{tabular}

Mean values within column followed the same letters are not significantly different; NS= not significant, LSD $(0.05)=$ Least Significant Difference at $5 \%$ level; $\mathrm{CV}=$ Coefficient of Variation

\subsubsection{Days to Physiological Maturity}

The main effects of both inter- and intra- row spacing were highly significant $(\mathrm{P}<0.01)$ on number of days taken by the crop to reach physiological maturity. However, their interaction did not show significant effect (Appendix Table $1)$. The narrowest inter row spacing $(20 \mathrm{~cm})$ took 104.78 days to attain physiological maturity which was significantly enhanced by wider spacing of 30,40 and $50 \mathrm{~cm}$ spacing (Table 2). The reason for this may be that in the wider inter row spacing, there existed a lower competition for resources like moisture and essential nutrients than the narrower inter row spacing. In addition, light would be intercepted better in the wider inter row spacing as compared to the narrower inter 
row spacing and also the better free air circulation in the canopy of the wider spaced rows could have its own contribution for shorter days to maturity.

With regard to the effects of intra row spacing, days to maturity was increased with lower intra row spacing $(5 \mathrm{~cm})$ as compared to wider intra row spacing. However, it did not differ significantly with $10 \mathrm{~cm}$ spacing but both these spacing resulted in significant delay in physiological maturity compared to $15 \mathrm{~cm}$ intra row spacing. The prolonged days to maturity in the case of narrower intra row spacing could be because of high competition for available resources in the soil, poor light interception and air circulation in the canopy as compared to the wider intra row spacing. In line with the present result, wider inter- and intra-row spacing hastened maturity of safflower [69]. But in disagreement with the report no significant effect of row spacing on maturity of soybean was reported [43]. In general, the difference in days to flowering and physiological maturity was very small which may not be practically important though statistically significant.

\subsection{Growth Parameters}

\subsubsection{Plant HeightatMaturity}

Main effect of inter- and intra- row spacing and their interaction had highly significant $(\mathrm{P}<0.01)$ effect on plant height of the chickpea crop (Appendix Table 2). The interaction of $20 \mathrm{~cm}$ inter- and $5 \mathrm{~cm}$ intra- row spacing resulted in significantly taller plants $(34.7 \mathrm{~cm})$ while the plants in $50 \mathrm{~cm}$ inter- and $15 \mathrm{~cm}$ intra- row spacing were the shortest in height $(31.7 \mathrm{~cm})($ Table 3$)$. This result might be due to the fact that as the spacing among plants decreased the interplant competition for light increased while sparsely populated plants intercepted sufficient sunlight that enhanced the lateral growth. In agreement with this, It was reported that plant height of chickpea and green bean was taller in higher plant population treatments due to more competition for light [34, 87, 102]. Similarly, others indicated that plant height significantly increased with the increase in plant density primarily because of lower amount of light intercepted by a single plant resulting into increased inter node length [76, 88]. More competition for light in narrow spacing resulted in taller plants while at wider spacing light distribution was normal [93]. Moreover, spacing experiment on soybean observed that increasing the density of plants led to significant increases in plant height [85]. In contrast with this, plant height was not affected by increasing plant density of faba bean reported by [84].

Table 3. Interaction effect of inter-and intra-row spacing on plant height (cm) of chickpea.

\begin{tabular}{lllll}
\hline \multirow{2}{*}{ Intra row spacing (cm) } & \multicolumn{5}{l}{ Inter row spacing (cm) } \\
\cline { 2 - 5 } & $\mathbf{2 0}$ & $\mathbf{3 0}$ & $\mathbf{4 0}$ & $\mathbf{5 0}$ \\
\hline 5 & $34.7^{\mathrm{a}}$ & $34.4^{\mathrm{bc}}$ & $34.3^{\mathrm{cd}}$ & $34.0^{\mathrm{e}}$ \\
10 & $34.5^{\mathrm{b}}$ & $34.1^{\mathrm{de}}$ & $34.1^{\mathrm{e}}$ & $32.1^{\mathrm{h}}$ \\
15 & $34.3^{\text {cd }}$ & $33.6^{\mathrm{f}}$ & $33.2^{\mathrm{g}}$ & $31.7^{\mathrm{i}}$ \\
$\operatorname{LSD}(0.05)=0.17 \mathrm{CV}(\%)=0.29$ & & & \\
\hline
\end{tabular}

Means in columns and rows followed by the same letters are not significantly different at $5 \%$ level of significance.

LSD $(0.05)=$ Least Significant Difference at $5 \%$ level; CV $=$ Coefficient of Variation

\subsubsection{Number of Primary Branches}

Analysis of variance revealed highly significant $(\mathrm{P}<0.01)$ effect of the main effects of inter- and intra- row spacing and significant effect $(\mathrm{P}<0.05)$ of their interaction on the number of primary branches per plant (Appendix Table 2). As a result, in response to the interaction of $50 \mathrm{~cm}$ inter- and $15 \mathrm{~cm}$ intra-row spacing resulted in the highest number of primary branches plant $^{-1}$ which was statistically at par with the interaction of $50 \mathrm{~cm}$ inter- and $10 \mathrm{~cm}$ intra-row spacing (Table 4).

Table 4. Interaction effect of inter- and intra-row spacing on number of primary branches plant $^{-1}$ of chickpea.

\begin{tabular}{lllll}
\hline Intra row & \multicolumn{4}{l}{ Inter row spacing $(\mathbf{c m})$} \\
\cline { 2 - 5 } spacing $(\mathbf{c m})$ & $\mathbf{2 0}$ & $\mathbf{3 0}$ & $\mathbf{4 0}$ & $\mathbf{5 0}$ \\
\hline 5 & $1.47 \mathrm{~h}$ & $2.20 \mathrm{fg}$ & $2.40 \mathrm{def}$ & $2.33 \mathrm{efg}$ \\
10 & $1.60 \mathrm{~h}$ & $2.47 \mathrm{cde}$ & $2.60 \mathrm{~cd}$ & $2.87 \mathrm{ab}$ \\
15 & $2.13 \mathrm{~g}$ & $2.47 \mathrm{cde}$ & $2.67 \mathrm{bc}$ & $3.00 \mathrm{a}$ \\
$\mathrm{LSD}(0.05)=0.251 \mathrm{CV}(\%)=6.329$ & & \\
\hline
\end{tabular}

Means in columns and rows followed by the same letters are not significantly different at $5 \%$ level of significance.

LSD $(0.05)=$ Least Significant Difference at 5\% level; CV $=$ Coefficient of Variation

The lowest number of branches (1.47) was found due to the interaction of $20 \mathrm{cminter}-$ and $5 \mathrm{~cm}$ intra-row spacing which did not differ significantly with the interaction of the same inter row spacing and $10 \mathrm{~cm}$ intra row spacing. The differential responses among the interaction of inter- and intra- row spacing might be due to differences in the access to growth factors by the plants grown under their respective environments. The increased number of branches under lower plant densities could be attributed to higher sunlight interception for photosynthesis. In contrast, the decreased number of branches in the narrower plant spacing might be due to the high competition for the resources and with the overlapped plant canopy, the crop might have been subjected to lower interception of sunlight which led to lower photo assimilation. This also indicated the plasticity response of plants to various plant spacing.

This result was in agreement with the finding that increased number of branches at the wider plant spacing for soybean and the reason for this was more interception of sunlight for photosynthesis, which may have resulted in production of more assimilate for partitioning towards the development of more branches [60]. In addition, others reported that the number of primary branches decreased with the increase in density of chickpea [91, 12]. Moreover, similar findings also reported faba bean, soybean and common vetch, respectively, reduced the number of branches with increased plant population $[7,11,4,56]$.

\subsection{Yield Components}

\subsubsection{Stand Count}

The main effects of inter- and intra- row spacing and their interactions were not significant on percent of final stand count of chickpea as compared to the initial count. This showed that the competition among the plants grown under varying plant population/densities had no remarkable effect 
on the survival of the plants at harvest.

Table 5. Main effect of inter- and intra-row spacing on stand count percentage of chickpea at harvest.

\begin{tabular}{ll}
\hline Treatment & Stand count $(\%)$ \\
\hline Inter row spacing $(\mathrm{cm})$ & \\
20 & 96.74 \\
30 & 97.12 \\
40 & 96.99 \\
50 & 96.70 \\
LSD $(0.05)$ & $\mathrm{NS}$ \\
Intra row spacing $(\mathrm{cm})$ & \\
5 & 97.15 \\
10 & 96.72 \\
15 & 96.79 \\
LSD $(0.05)$ & $\mathrm{NS}$ \\
CV $(\%)$ & 0.982 \\
\hline
\end{tabular}

$\mathrm{NS}=$ not significant, LSD $(0.05)=$ Least Significant Difference at $5 \%$ level; $\mathrm{CV}=$ Coefficient of Variation

\subsubsection{Number of Pods Per Plant}

The main effects of inter- and intra- row spacing and their interaction had a highly significant $(\mathrm{P}<0.01)$ effect on the number of pods plant ${ }^{-1}$ (Appendix Table 3). The highest number of podsplant ${ }^{-1}(34.7)$ was obtained with the interaction effect of $40 \mathrm{~cm}$ inter- and $10 \mathrm{~cm}$ intra- row spacing which had no significant difference with the number of pods found in response to the interaction of $50 \mathrm{~cm}$ inter row spacing with 10 and $15 \mathrm{~cm}$ intra row spacing (Table 6). Further, the latter two interactions were statistically at par with the interactions of $40 \mathrm{~cm}$ inter-and $15 \mathrm{~cm}$ intra-row spacing as well as $30 \mathrm{~cm}$ interand $10 \mathrm{~cm}$ intra- row spacing. In general, the number of pods plant $^{-1}$ increased with the increase in inter row spacing at the same level of intra row spacing. The lowest number of pods plant $^{-1}(16.7)$ was found in the closest spacing, i.e. $20 \mathrm{~cm}$ interand $5 \mathrm{~cm}$ intra-row spacing which was significantly lower than the other interactions. Thus, the interactions of $40 \mathrm{~cm} \times 10 \mathrm{~cm}$, $50 \mathrm{~cm} \times 10 \mathrm{cmand} 50 \mathrm{~cm} \times 15 \mathrm{~cm}$ resulted in an increase of 107.8 , 103.6 and $101.8 \%$ increase in number of pods over $20 \mathrm{~cm} \times$ $5 \mathrm{~cm}$ (Table 6).

Table 6. Interaction effect of inter-and intra-row spacing on number of pods plant $^{-1}$ of chickpea.

\begin{tabular}{lllll}
\hline Intra row & \multicolumn{5}{l}{ Inter row spacing $(\mathbf{c m})$} \\
\cline { 2 - 5 } spacing $(\mathbf{c m})$ & $\mathbf{2 0}$ & $\mathbf{3 0}$ & $\mathbf{4 0}$ & $\mathbf{5 0}$ \\
\hline 5 & $16.7^{\mathrm{g}}$ & $21.0^{\mathrm{f}}$ & $23.7^{\mathrm{e}}$ & $30.7^{\mathrm{d}}$ \\
10 & $22.7^{\mathrm{e}}$ & $33.0^{\mathrm{bc}}$ & $34.7^{\mathrm{a}}$ & $34.0^{\mathrm{ab}}$ \\
15 & $20.0^{\mathrm{f}}$ & $32.7^{\mathrm{c}}$ & $33.3^{\mathrm{bc}}$ & $33.7^{\mathrm{abc}}$ \\
$\mathrm{LSD}(0.05)=1.285 \mathrm{CV}(\%)=2.710$ & & \\
\hline
\end{tabular}

Means in columns and rows followed by the same letters are not significantly different at $5 \%$ level of significance, LSD $(0.05)=$ Least Significant Difference at $5 \%$ level; $\mathrm{CV}=$ Coefficient of Variation

The difference among the inter row spacing in response to intra row spacing on number of pods might be due to the fact that, as the plant population increased there was high competition for the growth factors as compared to wider spacing which had impact on the number of pods per plant. The reduced competition for light and reduced overlapping from adjacent chickpea plants could have enabled the plants grown at wider spacing to utilize its energy for more branching (Table 4) and subsequently, the greater number of pods plant $^{-1}$. In agreement to the present result, higher number of pods plant ${ }^{-1}(41.47)$ was reported in the wider inter row spacing $(45 \mathrm{~cm})$ of chickpea [50]. Similarly, researches worked on faba bean reported that the development of more and vigorous leaves on low plant density helped to improve the photosynthetic efficiency of the crop and supported higher number of pods $[4,42,1]$.

\subsubsection{Number of Seeds Per Pod}

Table 7. Main effects of inter-and intra-row spacing on number of seeds pod $^{1}$ and hundred seed weight ( $g$ ) of chickpea.

\begin{tabular}{lll}
\hline Treatment & $\begin{array}{l}\text { Number of seeds per } \\
\text { pod }\end{array}$ & $\begin{array}{l}\text { Hundred seed } \\
\text { weight }(\mathbf{g})\end{array}$ \\
\hline Inter row spacing $(\mathrm{cm})$ & & \\
20 & $1.10^{\mathrm{c}}$ & $21.58^{\mathrm{c}}$ \\
30 & $1.17^{\mathrm{b}}$ & $24.24^{\mathrm{b}}$ \\
40 & $1.16^{\mathrm{b}}$ & $24.46^{\mathrm{ab}}$ \\
50 & $1.23^{\mathrm{a}}$ & $25.38^{\mathrm{a}}$ \\
LSD $(0.05)$ & 0.040 & 0.962 \\
Intra row spacing $(\mathrm{cm})$ & & \\
5 & $1.12^{\mathrm{b}}$ & $22.48^{\mathrm{b}}$ \\
10 & $1.18^{\mathrm{a}}$ & $24.52^{\mathrm{a}}$ \\
15 & $1.19^{\mathrm{a}}$ & $24.75^{\mathrm{a}}$ \\
LSD $(0.05)$ & 0.035 & 0.833 \\
CV $(\%)$ & 3.5 & 4.1 \\
\hline
\end{tabular}

Means in column followed by the same letter are not significantly different at $5 \%$ level of significance; LSD $(0.05)=$ Least Significant Difference; $C V=$ Coefficient of Variation

The analysis of variance showed a highly significant $(\mathrm{P}<0.01)$ effect of the main effects of inter- and intra- row spacing, but their interaction had no significant effect on the number of seeds $\operatorname{pod}^{-1}$ (Appendix Table 3). Significantly higher number of seeds $\operatorname{pod}^{-1}(1.23)$ was obtained at $50 \mathrm{~cm}$ than the other inter row spacing (Table 7). There was no significant difference between 30 and $40 \mathrm{~cm}$ inter row spacing while $20 \mathrm{~cm}$ inter row spacing recorded significantly lower number of seeds pod $^{-1}$ than the other inter row spacing. The plants grown in plots with $50 \mathrm{~cm}$ inter row spacing had 11.8 , $5.1,6.0 \%$ higher number of seed pod, ${ }^{-1}$ respectively, than the plants grown in 20,30 and $40 \mathrm{~cm}$ inter row spacing. Plants compete for limited resources being essential for their life, i.e. light, water, and nutrients. Yet, whole plant growth and competitive ability depends not only on the photosynthetic rate of individual leaves, but also on the geometry and dynamics of a plant's canopy, and the pattern of energy all Cation among all organs [13].

On the other hand, $15 \mathrm{~cm}$ intra row spacing resulted in the highest number of seeds $\operatorname{pod}^{-1}$ which was statistically in parity with $10 \mathrm{~cm}$ intra row spacing (Table 7). Both the intra row spacing registered significantly higher number of seeds $\operatorname{pod}^{-1}$ than $5 \mathrm{~cm}$ intra row spacing. This increase in the number of seeds pods ${ }^{-1}$ was 6.3 and $5.4 \%$ over $5 \mathrm{~cm}$ with 10 and $15 \mathrm{~cm}$ intra row spacing. As the number of plants within a row increased, intra row plant competition got increased while light interception reduced and resulted in decreased number of seeds pod $^{-1}$. In agreement with the present result, 
the number of seeds per pod reported increased with decreased plant density of faba bean $[2,10,1]$. Moreover, in safflower higher number of seeds per pod was reported in association with wider inter and intra-row spacing [69]. In accordance with the present result, decreased number of seeds pod $^{-1}$ from 1.87 to 1.81 was reported as seed rate increased from $60 \mathrm{~kg} \mathrm{ha}^{-1}$ to $75 \mathrm{~kg} \mathrm{ha}^{-1}$ on chickpea [50].

\subsubsection{Hundred Seed Weight}

The main effects of inter- and intra- row spacing were highly significant $(\mathrm{P}<0.01)$ whereas their interaction had no significant effect on the hundred seed weight of chickpea (Appendix Table 3). The highest hundred seed weight $(25.38 \mathrm{~g})$ was observed with $50 \mathrm{~cm}$ inter row spacing which had no significant difference with $40 \mathrm{~cm}$ inter row spacing. On the other hand, no significant difference in 100 seed weight existed between 30 and $40 \mathrm{~cm}$ inter row spacing. However, $20 \mathrm{~cm}$ inter row spacing had significantly the lowest 100 seed weight compared to the other inter row spacing (Table 6). The variation in 100 seed weight due to intra row spacing was similar to the response of number of seeds pod $^{-1}$ wherein the 100 seed weight increased with an increase in intra row spacing but no significant difference was observed between 10 and $15 \mathrm{~cm}$. The 100 seed weight was 8.3 and $9.2 \%$ lower at $5 \mathrm{~cm}$ than at 10 and $15 \mathrm{~cm}$ intra row spacing (Table 7).

Decreasing inter- and intra- row spacing might have increased inter specific competition which eventually caused reduction in weight of seeds. Moreover, decreasing plant density might have caused more sunlight to penetrate the canopy that made plants to benefit more from the natural environment. Thus, this might have caused an increase in number of branches and the increased level of photosynthesis resulting in more assimilates translocated and stored in seeds. In agreement with the result obtained, hundred seed weight that decreased from $19.5 \mathrm{~g}$ to $17.56 \mathrm{~g}$ was reported as plant density increased from $40 \mathrm{~cm} \times 16 \mathrm{~cm}$ to $40 \mathrm{~cm} \times 7 \mathrm{cmin}$ haricot bean [89]. Similarly, other authors also reported that hundred seed weight of faba bean was negatively related with plant density [4, 95, 59]. Moreover, higher hundred seed weight $(29.87 \mathrm{~g})$ was reported in the wider inter row spacing of $45 \mathrm{~cm}$ than $30 \mathrm{~cm}$ inter row spacing of chickpea [50]. However, the result of this experiment was not in line with other authors who reported that individual seed weight is rarely affected by growth factors except in case of severe water stress and hot desiccating winds that caused forced maturity [95]. Similarly, no significant effect of plant density was obtained on hundred seed weight of soya bean [54].

\subsection{Yield and Harvest Index}

\subsubsection{Above ground Dry Biomass Yield ( $\left.\mathrm{kg} \mathrm{ha}^{-1}\right)$}

The analysis of variance revealed that the main effects of inter row spacing and intra row spacing showed a highly significant $(\mathrm{P}<0.01)$ effect on above ground dry biomass. Moreover, the interaction effect of inter row and intra row spacing had also a highly significant $(\mathrm{P}<0.01)$ effect (Appendix Table 4). The highest above ground dry biomass $\left(10650.27 \mathrm{kgha}^{-1}\right)$ was recorded at $20 \mathrm{~cm} \times 5 \mathrm{~cm}$ spacing combination and the lowest above ground dry biomass $\left(2186.69 \mathrm{kgha}^{-1}\right)$ was recorded at $50 \mathrm{~cm} \times 15 \mathrm{~cm}$ spacing combination (Table 8). For all of the inter row spacing, the highest number of above ground dry biomass were recorded as the intra row spacing decreased. The highest total dry biomass at the highest density of plants might be due to more number of plants per unit area. However, if the number of plants per unit area keeps on increasing, the aboveground dry biomass will reduce as there is lodging problem and lower photosynthetic efficiency in highly crowded plant population. In agreement with this study, an author reported that dry biomass per ha was significantly increased with increased plant density $(40 \mathrm{~cm} \times 10 \mathrm{~cm})$ on haricot bean [89]. Similar report revealed increment of total dry biomass with increasing plant population of soya bean up to a certain point and subsequently no addition in biological yield can be obtained thus decrease in economic yield [88]. In line with this, lower plant densities of 5 and 7 plants $\mathrm{m}-1$ resulted in a greater aboveground DM biomass and number of pods per plant of the common bean; grain yield was not decreased [101].

Table 8. Interaction effect of inter-and intra-row spacing on above ground dry biomass yield $\left(\mathrm{kg} \mathrm{ha}^{-1}\right)$ of chickpea.

\begin{tabular}{lllll}
\hline \multirow{2}{*}{ Intra row spacing (cm) } & \multicolumn{4}{l}{ Inter row spacing $(\mathbf{c m})$} \\
\cline { 2 - 5 } & $\mathbf{2 0}$ & $\mathbf{3 0}$ & $\mathbf{4 0}$ & $\mathbf{5 0}$ \\
\hline 5 & $10650.27^{\mathrm{a}}$ & $7838.76^{\mathrm{b}}$ & $5955.64^{\mathrm{d}}$ & $5249.44^{\mathrm{e}}$ \\
10 & $7055.58^{\mathrm{c}}$ & $4884.22^{\mathrm{f}}$ & $3814.96^{\mathrm{g}}$ & $3228.76^{\mathrm{h}}$ \\
15 & $4840.17^{\mathrm{f}}$ & $3421.76^{\mathrm{h}}$ & $2590.87^{\mathrm{i}}$ & $2186.69^{\mathrm{j}}$ \\
$\mathrm{LSD}(0.05)=233.80 \mathrm{CV}(\%)=2.68$ & & & \\
\hline
\end{tabular}

Means in column and row followed by the same letters are not significantly different at $5 \%$ level of significance.

LSD $(0.05)=$ Least Significant Difference at 5\% level; CV= Coefficient of Variation.

\subsubsection{Grain Yield ( $\left.\mathrm{kg} \mathrm{ha}^{-1}\right)$}

The main effects of inter- and intra- row spacing and their interaction showed a highly significant $(\mathrm{P}<0.01)$ effect on grain yield (Appendix table 4 ). The interaction of $30 \mathrm{~cm}$ interand $10 \mathrm{~cm}$ intra- row spacing resulted in the highest grain yield $\left(1219 \mathrm{~kg} \mathrm{ha}^{-1}\right)$ which was statistically at par with the grain yield obtained with the interactions of $40 \mathrm{~cm} \times 5 \mathrm{~cm}$, $30 \mathrm{~cm} \times 15 \mathrm{~cm}$ and $20 \mathrm{~cm} \times 15 \mathrm{~cm}$ spacing (Table 9). The lowest grain yield $\left(733 \mathrm{~kg} \mathrm{ha}^{-1}\right)$ was recorded with the interaction of $50 \mathrm{~cm} \times 15 \mathrm{~cm}$ which was statistically similar to the yield obtained with the interaction of $40 \mathrm{~cm} \times 15 \mathrm{~cm}$ spacing. The possible reason could be that, when inter-and intra-row spacing was decreased, number of plants per unit area increased, resulting in higher yield. Decreased inter- and intra-row spacing implied high plant density, which is concomitantly equal to high yield with every successful pod formation per plant. However, this could be possible only up to certain level of population. At extremely higher population $(20 \mathrm{~cm} \times 5 \mathrm{~cm})$, the adverse effect on the yield was noticed which might be due to intense interplant competition and floral abortion. In spite of lower number of branches plant ${ }^{-1}$ (Table 4), number of podsplant ${ }^{-1}$ (Table 6), number of seeds $\operatorname{pod}^{-1}$ and hundred seed weight (Table 7) at narrow inter- and 
intra- row spacing and or their interaction, i.e. $20 \mathrm{~cm} \times 5 \mathrm{~cm}$, the grain yield ha ${ }^{-1}$ was significantly higher as compared to the interaction of wider inter- and intra- row spacing $(50 \mathrm{~cm}$ $\times 15 \mathrm{~cm}$ )which showed that the main determinant of yield was the plant population which along with other yield attributes contributed towards significant increase in grain yield (Table 9). It can thus be seen that, the total yield per unit area depended not only on the performance of individual plant but also on the number of plants per unit area as confirmed in this study. Further, other reason for seed-yield enhancement under narrow planting could be attainment of sufficient leaf area index (LAI) to produce maximal light interception during the grain formation. But in the wide inter- and intrarow spacing even though the yield per individual plant was higher, since the plant population reduced the grain yield showed decrement. In the same manner, at narrow-row planting seed yield enhancement in determinate soybean was due to greater light interception during pod filling, and not greater leaf area development and dry matter production before this time [13], [92].

Similarly, higher grain yield of chickpea was reported at average $(45 \mathrm{~cm} \times 7.5 \mathrm{~cm}) \quad$ spacing combination than $35 \mathrm{~cm} \times 5 \mathrm{~cm}$ and $55 \mathrm{~cm} \times 10 \mathrm{~cm}$ spacing combinations [18]. Moreover, reports showed increased yield from higher plant populations are primarily the result of increased light interception during grain-filling by the crop canopy of soya bean [8, 19]. This idea was also in agreement with other authors who reported that the yield per unit area was increased with increasing plant density due to efficient utilization of growth factors [88]. Similarly, the seed yield was increased by $30.81 \%$ and $15.53 \%$ as inter and intra -row spacing decreased from 40 to $20 \mathrm{~cm}$ and 15 to $10 \mathrm{~cm}$, respectively [100]. Further, reports revealed that too narrow or too wide spacing affect yield due to competition for resources and shading effect $[79,72]$. In the case of too wide spacing, yield reduction can occur due to inefficient utilization of the growth factors.

Table 9. Interaction effect of inter- and intra row spacing on grain yield $\left(\mathrm{kgha}^{-1}\right)$ of chickpea.

\begin{tabular}{lllll}
\hline Intra row & \multicolumn{4}{l}{ Inter row spacing $(\mathbf{c m})$} \\
\cline { 2 - 5 } spacing $(\mathbf{c m})$ & $\mathbf{2 0}$ & $\mathbf{3 0}$ & $\mathbf{4 0}$ & $\mathbf{5 0}$ \\
\hline 5 & $903^{\text {ef }}$ & $1049^{\mathrm{bcd}}$ & $1134^{\mathrm{abc}}$ & $1019^{\text {cde }}$ \\
10 & $1088^{\mathrm{bc}}$ & $1219^{\mathrm{a}}$ & $1049^{\mathrm{bcd}}$ & $957^{\text {def }}$ \\
15 & $1150^{\mathrm{ab}}$ & $1134^{\mathrm{abc}}$ & $856^{\mathrm{fg}}$ & $733^{\mathrm{g}}$ \\
$\mathrm{LSD}(0.05)=125.5 \mathrm{CV}(\%)=7.2$ & & \\
\hline
\end{tabular}

Means in columns and rows followed by the same letters are not significantly different at $5 \%$ level of significance.

LSD $(0.05)=$ Least Significant Difference at $5 \%$ level; $\mathrm{CV}=$ Coefficient of Variation.

\subsubsection{Harvest Index}

There was a significant difference recorded on the main effects of inter row spacing, intra row spacing and their interaction (Appendix Table 4). The highest harvest index $(33.6 \%)$ was achieved for the interaction of $50 \mathrm{~cm}$ inter- and $15 \mathrm{~cm}$ intra- row spacing which was statistically at par with the harvest index obtained with $40 \mathrm{~cm} \times 15 \mathrm{~cm}$ and $30 \mathrm{~cm} \times 15 \mathrm{~cm}$ (Table 10). The lowest harvest index $(9.7 \%)$ was accrued with the combination of narrowest inter- and intra- row spacing, i.e. $20 \mathrm{~cm} \times 5 \mathrm{~cm}$. This reduction in harvest index in narrower spacing might be due to the higher plant population per unit area which might have increased the flower abortion due to competition for nutrients, moisture and solar radiation. Similar result reported by other authors indicated maximum harvest index $(41.66 \%)$ in the highest row spacing $(45 \mathrm{~cm})$ of chickpea than $15 \mathrm{~cm}$ row spacing [50].

Table 1. Interaction effect of inter-and intra row spacing on harvest index (\%) of chickpea.

\begin{tabular}{lllll}
\hline \multirow{2}{*}{ Intra row spacing $(\mathbf{c m})$} & \multicolumn{4}{l}{ Inter row spacing $(\mathbf{c m})$} \\
\cline { 2 - 5 } & $\mathbf{2 0}$ & $\mathbf{3 0}$ & $\mathbf{4 0}$ & $\mathbf{5 0}$ \\
\hline 5 & $9.7^{\mathrm{g}}$ & $13.4^{\mathrm{f}}$ & $19.1^{\mathrm{e}}$ & $19.4^{\mathrm{e}}$ \\
10 & $15.4^{\mathrm{f}}$ & $25.0^{\mathrm{cd}}$ & $27.5^{\mathrm{bc}}$ & $29.7^{\mathrm{b}}$ \\
15 & $23.8^{\mathrm{d}}$ & $33.2^{\mathrm{a}}$ & $33.0^{\mathrm{a}}$ & $33.6^{\mathrm{a}}$ \\
$\mathrm{LSD}(0.05)=3.24 \mathrm{CV}(\%)=8.096$ & & & \\
\hline
\end{tabular}

Means in columns and rows followed by the same letters are not significantly different at $5 \%$ level of significant;

LSD $(0.05)=$ Least Significant Difference at $5 \%$ level; CV $=$ Coefficient of Variation.

\section{Conclusion}

Chickpea is the most important leguminous food grain in the diets of people in South and West Asia and northern Africa. In Africa, Ethiopia stands first in area $(213,187 \mathrm{ha})$ and production $(284,640 \mathrm{t})$, but third in productivity $(1335.2$ $\mathrm{kg} \mathrm{ha}{ }^{-1}$ ) after Egypt and Sudan. This clearly indicates the importance of chickpea in Ethiopian agriculture. The crop has a major role in the daily diet of the rural community and poor sectors of urban population and its straw is used for animal feed. Chickpea also fetches good price when sold in local market and hence generates cash to farmers. Despite these facts, the yield of chickpea in Ethiopia is extremely low which can be attributed to factors such as water deficit, diseases, insects, weeds infestations and poor agronomic practices.

It is clear that both too narrow and too wide spacing do affect grain yields through competition (for nutrients, moisture, air, radiation, etc) and due to the effect of shading. In the latter case (too wide spacing), yield reduction can Ccur due to in efficient utilization of the growth factors. Normally, as population increases yield also increases proportionally. After, it reached a certain level the yield declines.

Accordingly, the experiment was conducted to determine the effect of inter and intra row spacing on yield components and yield of a Desi type chickpea variety Naatolii. A factorial experiment was conducted in RCBD in three replication with 4 inter row spacing, i.e. $20 \mathrm{~cm}, 30 \mathrm{~cm}, 40 \mathrm{~cm}$ and $50 \mathrm{~cm}$ and three intra row spacing of $5 \mathrm{~cm}, 10 \mathrm{~cm}$, and $15 \mathrm{~cm}$.

Days to $50 \%$ flowering was highly significantly affected by both inter row spacing and intra row spacing. Row spacing of $50 \mathrm{~cm}$ was earlier (49.56 days) while row spacing $20 \mathrm{~cm}$ took the longest number of days to flower (50.67 days). 
And regarding the intra row spacing, $5 \mathrm{~cm}$ intra row spacing took longer days than the others and $15 \mathrm{~cm}$ intra row spacing took the least days to $50 \%$ flowering (49.58 days). Days to physiological maturity increased with decreased inter row spacing from 103.78 at $50 \mathrm{~cm}$ to 104.78 days at $20 \mathrm{~cm}$. Similarly, days to maturity increased from 103.83 to 104.50 days as intra row spacing decreased from $15 \mathrm{~cm}$ to $5 \mathrm{~cm}$.

The interaction effect of inter row and intra row spacing was highly significant on plant height. The tallest plant $(34.7 \mathrm{~cm})$ was recorded in $20 \mathrm{~cm} \times 5 \mathrm{~cm}$ spacing while the shortest plant height $(31.7 \mathrm{~cm})$ was recorded at $50 \mathrm{~cm} \times 15 \mathrm{~cm}$ spacing. The interaction of inter row and intra row spacing had a significant effect on the number of primary branches of chickpea. For all of the inter row spacing the number of primary branches was increased as the intra row spacing increased.

The interaction of inter row spacing and intra row spacing showed a highly significant effect on number of pods per plant. The highest number of pods plant ${ }^{-1}$ (34.7) was obtained with the interaction effect of $40 \mathrm{~cm}$ inter- and $10 \mathrm{~cm}$ intra- row spacing which had no significant difference with the number of pods found in response to the interaction of $50 \mathrm{~cm}$ inter row spacing with 10 and $15 \mathrm{~cm}$ intra row spacing while the lowest number of pods plant ${ }^{-1}$ (16.7) was recorded at $20 \mathrm{~cm}$ $\times 5 \mathrm{~cm}$ spacing.

Number of seeds per pod was highly significantly affected by inter row spacing and intra row spacing. The highest number of seed per pod (1.23) was obtained at $50 \mathrm{~cm}$ inter row spacing and the lowest number of seeds per pod (1.10) was recorded from the $20 \mathrm{~cm}$ inter row spacing. On the other hand, from the narrowest $(5 \mathrm{~cm})$ intra row spacing the lowest number of seeds per pod (1.12) was recorded and the highest number of seeds per pod (1.19) was recorded at the $15 \mathrm{~cm}$ intra row spacing. The main effects of inter row spacing and intra row spacing were highly significant on the hundred seed weight. The widest inter row spacing $(50 \mathrm{~cm})$ gave the highest hundred seed weight $(25.38 \mathrm{~g})$ while the narrower inter row spacing $(20 \mathrm{~cm})$ gave the lowest hundred seed weight $(21.58$ g).

Interaction effects of inter- and intra- row spacing had a highly significant effect on the harvest index. For all of the inter row spacing the harvest index was increased as the intra row spacing increased. The interaction effect of inter row and intra row spacing had also a highly significant effect on the aboveground dry biomass yield. The highest above ground dry biomass $\left(10650.27 \mathrm{~kg} \mathrm{ha}^{-1}\right)$ was recorded at $20 \mathrm{~cm} \times 5 \mathrm{~cm}$ spacing while the lowest number of above ground dry biomass $\left(2186.69 \mathrm{~kg} \mathrm{ha}^{-1}\right)$ was recorded at $50 \mathrm{~cm} \times 15 \mathrm{~cm}$ spacing.

The interaction effect of the two factors was highly significant on grain yield. The interaction of $30 \mathrm{~cm}$ interand $10 \mathrm{~cm}$ intra-row spacing gave the highest grain yield $\left(1219 \mathrm{~kg} \mathrm{ha}^{-1}\right)$ which was statistically at par with the grain yield obtained with the interactions of $40 \mathrm{~cm} \times 5 \mathrm{~cm}, 30 \mathrm{~cm} \times$ $15 \mathrm{~cm}$ and $20 \mathrm{~cm} \times 15 \mathrm{~cm}$ spacing. On the other hand, the lowest grain yield $\left(733 \mathrm{~kg} \mathrm{ha}^{-1}\right)$ was recorded with the interaction of $50 \mathrm{~cm} \times 15 \mathrm{~cm}$ which was statistically at par with the yield obtained with the interaction of $40 \mathrm{~cm} \times$ $15 \mathrm{~cm}$ spacing.

In conclusion, the results from the study indicated that inter row spacing and intra row spacing had a significant influence on the phenology, growth, yield components and yield of chickpea. The inter row and intra row spacing of $20 \mathrm{~cm} \times 15 \mathrm{~cm}, 30 \mathrm{~cm} \times 10 \mathrm{~cm}, 30 \mathrm{~cm} \times 15 \mathrm{~cm}$ and $40 \mathrm{~cm} \times 5 \mathrm{~cm}$ showed no significant differences in grain yield. But among these spacing combinations, $30 \mathrm{~cm} \times 10 \mathrm{~cm}$ or $30 \mathrm{~cm} \times$ $15 \mathrm{cmspacing}$ can be tentatively suggested for the area. However, as this is one season experiment at one location, the experiment has to be repeated over locations and seasons with inclusion of more varieties to reach at a more reliable conclusion.

\section{References}

[1] Abdel, L. Y. I. 2008. Effect of seed size and plant spacing on yield and yield components of faba bean (Viciafaba L.). Research Journal of Agriculture Biological Science, 4(2): 146148.

[2] Abo El-Zahab, A. A., A. A. Al-Babawy and I. S. Nidway. 1981. Density studies on faba beans (Viciafaba L.) II: Growth parameters. Agronomy and Crop Science Journal, 150: 303312 .

[3] Adamu, M. 1995. Effects of sowing date, weeding frequency and seed rate on yield of faba bean grown on pellicvertisol at Sheno. Proceeding; Conference of Agronomy and Crop Physiology SCiety of Ethiopia, Addis Ababa. pp. 120-126.

[4] Al-Aduselam, M. A. and K. S. Abdai. 1995. Effect of plant density and certain pesticides on growth, yield and rhizobial nodulation of faba bean. King Saudi University, Agricultural Science Journal, 7: 249-257.

[5] Alihan Cokkizgin, 2012. Botanical characteristics of chickpea genotypes (Cicer arietinum L.) under different plant densities in organic farming. Scientific Research and Essays, 7(4): 498503.

[6] Amare, G; Mekonnen, W. M. and T. Asfwa. 1993. Effect of method and rate of seeding on faba bean yield. pp. 18-19 In: Nile Valley Regional Program on Cool Season Food Legumes. Annual Report 1991/92, Ethiopia. ICARDA/NVRP-024.

[7] Amato, G., R. Cibella, D. Giambalvo and Gristina, L. 1992. Observations of the reproductive development in faba bean (Viciafaba L. var. equina) in relation to plant density pp. 245 246. In: PrCeedings of the $1^{\text {st }}$ European Conference on Grain Legumes 1-3 June, Angers, France.

[8] Andrade FH., Calviño P., Cirilo A. and Barbieri P. 2002. Yield responses to narrow rows depend on increased radiation interception. Agronomy Jounal. 94: 975-980.

[9] Asossa Agricultural Research Center (AARC). 2007. Farming system survey document. (unpublished report), Asossa, Benishangul-Gumuz Regional State, Ethiopia.

[10] Ayaz, S., D. L. McNeil, B. A. McKenzie and G. D. Hill. 2001. Density and sowing depth effects on yield components of grain legumes. Proceedings of Agronomic Society. New Zealand, 29: 9-15. 
[11] Aydogdu, L. and Acikgoz, E. 1995. Effect of seeding rate on seed and hay yield in common vetch (Vicia sativa L.). Agronomy and Crop Science Journal, 174: 181-187.

[12] Bakry BA, Elewa TA, El-Karamany MF, Zeidan MS, Tawfik MM. 2011. Effect of row spacing on yield and its components of some faba bean varieties under newly reclaimed sandy soil condition. World Journal of Agricultural Science, 7(1): 68-72.

[13] Ball, R. A., L. C. Purcell and E. D. Vories. 2000. Short-season soybean yield compensation in response to population and water regime. Crop Science, 40: 1070-1078

[14] Beech, D. F. and G. L. Leach. 1989. Effect of plant density and row spacing on the yield of chickpea (cv. Tyson) grown on the Darling Down, South-eastern Queens land. Australia Journal of Experimental Agriculture 29(2):241-246.

[15] Bekele Shiferaw, Johns R., Silim S., Hailemariam Teklewold and Gwata E., 2007. Analysis of production costs market opportunities and competitiveness of Desie and Kabuli chickpea in Ethiopia. IPMS (improving productivity and market success) of Ethiopian farmers project working paper 3 . ILRI, Nairobi, Kenya. pp 48.

[16] Bekele Shiferaw, Bantilan C, Gupta SC and Shetty SVR. 2004. Research spillover benefits and experiences in interregional technology transfer: Assessment and synthesis of some findings. Research Report. ICRISAT (International Crops Research Institute for the Semi-Arid Tropics), Patancheru, India. pp 131.

[17] Bennet, J. P.; Adams, M. W. and C. Burga. 1977. Pod yield component variation and inter correlation in Phaseolus vulgaris L. as affected by planting density. Crop Science, 17:73-75.

[18] Biabani, A. 2011. Effect of Plant Density on Yield and Yield Components of Chickpea (CicerarietinumL.)Grown under Environmental Condition of Golestan, Iran. Journal of Agricultural Science and Technology, 5:32-33

[19] Caliskan S., Aslan M., Uremis I. and Caliskan ME. 2007. The effect of row spacing on yield and yield components of full season and double cropped soybean. Turky Journal of Agriculture and Forestry. 31: 147-154.

[20] Chavan, J. K., Kadam, S. S. and Salunke, D. K. 1986. Biochemistry and technology of chickpea (Cicerarietinum) seeds. CRC Crit. Rev. Food Sci. Nutr., 25: 107-132.

[21] Christodoulou, V, Bampidis, V. A., Hucko, B., Ploumi, K., Iliadis, C., Robinson, P. H. and Mudrik, Z. 2005. Nutritional value of chickpeas in rations of lactating ewes and growing lambs. Animal Feed Science and Technology, 118: 229-241.

[22] CSA (Central Statistical Authority). 2013. Crop Production Sample Survey Report on the area and production forecast for major crops (private peasant holdings 'Meher' season). The FDRE Statistical Bulletin. Addis Ababa, Ethiopia 5: 10-14.

[23] CSA (Central Statistical Authority). 2000. Time series data on production and yield of major crops. Statistical Bulletin. Addis Ababa. 56: 1-3.

[24] CSA (Central Statistical Agency). 2006. Federal Democratic Republic of Ethiopia. Statistical Abstract. 2005. CSA, Addis Ababa, Ethiopia.

[25] Davis, P. H. 1970. Flora of Turkey and the East Aegean Islands. Edinburgh University Press, pp. 267-274.
[26] Day, P. R. 1965. Hydrometer Methods of Particle Size analysis. In: C. A. Black (ed.), Agronomy No. 9. Part 1. American society of agronomy. Madison, Wisconsin, USA.

[27] Dewis, J. and P. freitas. 1975. Physical and chemical methods of soil and tissue analysis. FAO Bulletin No. 10. Rome. Pp275.

[28] Donald, C. M. 1963. Competition among crop and pasture plants. Advanced Agronomy, 15: 1-118.

[29] EARO (Ethiopian Agricultural Research Organization). 2004. Directory of Released Crop Varieties and their Recommended Cultural Practices, Addis Ababa, Ethiopia.

[30] Egli, D. B. 1988. Plant density and soybean yield. Crop Science, 28: 977-980.

[31] FAOSTAT, 2012. Statistical databases and data - sets of the Food and Agriculture Organization of the United Nations. http://faostat.fao.org/default.aspx, Accessed on September, 2012

[32] Farag, S. A. and H. A. El-Shamm. 1994. Effect of irrigation intervals and plant distances on the growth and seed yield of broad bean plants. Annual Agricultural Science, Moshtohor, 32(4): 2071-2081.

[33] FDRE (Federal Democratic Republic of Ethiopia). 2010. Extension Package for Pulse Production and Improved Management Practices. Agricultural Extension Directorate. Amharic version. Addis Ababa, Ethiopia.

[34] Felton W. L., Marcellos H. and Murison R. D. 1996. The effect of row spacing and seeding rate on chickpea yield in Northern New South Wales. Proceeding $8^{\text {th }}$ Australia Agronomy Conference Toowoomba, pp. 251-253.

[35] Gebre Hadgu. 2006. Effect of planting method and spacing on yield and yield attributes of sesame (Sesamonindicum L) in the low land plain of Humera, western Tigray, Ethiopia. M. Sc. Thesis Presented to Haramaya University. Haramaya, Ethiopia.

[36] Geletu Bejiga. 1994. Forty years of Research Experience. DebreZeit Agricultural Research Center (1955-1994). DebreZeit, Ethiopia.

[37] GeletuBejiga. 1972. Chickpea Production in Ethiopia. In: PrCeedings of the International Workshop on Chickpea Improvement, (Green, J. M., Nene, Y. L and Smithson, J. B. eds), pp. 236-242, ICRISAT (International Crops Research Institute for the Semi-Arid Tropics), Andhra Pradesh, India.

[38] GeletuBejiga and AbebeTullu. 1982. The influence of planting dates on the yield of three chickpea (CicerarietinumL) varieties. Ethiopian Journal of Agricultural Science, 14: 6166.

[39] [39] GeletuBejiga, Million Eshete and YadetaAnbessa. 1996. Improved cultivars and production technology of chickpea in Ethiopia. DebreZeit Agricultural Research Center (DZARC), DebreZeit, Ethiopia.

[40] Gomez, K. A. and A. A. Gomez. 1984. Statistical prCedures for agricultural research, $2^{\text {nd }}$ ed. John Willy and Sons, Newyork. p 680.

[41] Grafton, K. F, A. A Schneiter and B. J. Nagle. 1988. Row spacing, plant population and genotype and row spacing interaction effects on yield and yield components of dry bean. Agronomy Journal, 80: 631-634. 
[42] Hodgson, G. L. and G. E. Blackman. 2005. An Analysis of the Influence of Plant Density on the Growth of Viciafaba. L. Journal of Experimental Botany. Oxford University. 7:147165.

[43] Holshouser, D. L and P. W. Joshua. 2002. Plant population and row spacing effects on early soybean production systems in Mid Atlantic, USA Agronomy Journal, 94: 603-611.

[44] ICRISAT (International Crops Research Institute for the Semi-Arid Tropics). 2010. Chickpea Seed Production Manual, patancheru 502324 Andhra Pradesh, India.

[45] Jackson, M. L. 1958. Soil Chemical Analysis Practice Hall of India. New Delhi.

[46] James, N. and S. P. Singh. 1985. Effects of 1Cation and plant density on yield and architectural traits in dry beans. Journal of Crop Science, 23: 579-584.

[47] Johnson, R. R.; Green, D. E. and C. W. Jordan. 1982. What is the best soybean row width: A U.S. Perspective. Crops and Soils. 34 (4): 10-13.

[48] Joshi PK, ParthasaratyRao P, Gowda CLL, Jones RB, Silim SN, Saxena KB and Kumar J. 2001. The world chickpea and pigeonpea economies: Facts, trends, and outlook. ICRISAT (International Crops Research Institute for the Semi-Arid Tropics), Patancheru, India. p 62.

[49] Kay, D. E. 1979. Crop and Product Digest-Food Legumes. No. 3, London: Tropical Products Institute, pp. 50-51.

[50] Khan, E. A., M. Aslam, H. K. Ahmad, M. Ayaz and A. Hussain. 2010. Effect of row spacing and seeding rates on growth yield and yield components of chickpea. Sarhad Journal of Agriculture, 26(2): 201-211

[51] Ladizinisky, G. 1975. A new Cicer from Turkey notes from the Royal Botanical Garden Edinburgh. Indian Journal of Experimental Biology.34: 201- 202.

[52] Landon, J. R. 1984. Booker tropical soil manual (ed.). A hand book for soil survey and agricultural land evaluation in the tropics and subtropics. Booker Agriculture International Limited, Bath.

[53] LegesseDadi, SenaitRegassa, AsnakeFikre and DemissieMitiku. 2005. Adoption of chickpea varieties in the central highlands of Ethiopia. Research Report 62. EARO (Ethiopian Agricultural Research Organization), Addis Ababa, Ethiopia.

[54] Lemlem H/Giorgis. 2011. Effect of $\mathrm{N}$ fertilizer and plant density on yield, seed quality, and oil content of soybean (Glycine $\max$ L. Merr) at Hawassa, southern Ethiopia. M. Sc. Thesis Presented to Haramaya University, Ethiopia.

[55] Lopez-Bellido, R. J., L. Lopez-Bellido, F. J. Lopez-Bellido and J. E. Castillo. 2003. Faba bean (Viciafaba L.) response to tillage and soil residual nitrogen in a continuous rotation with wheat (Triticumaestivum L.) under rain fed Mediterranean conditions. Agronomy Journal, 95: 1253-126.

[56] Loss, S., M. K. L. Siddique and A. Crombie. 1998. Response of faba bean (ViciafabaL.) to sowing rate in southwestern Australia, II: Canopy development, radiation absorption and dry matter partitioning. Australian Agriculture Research Journal, 49(6): 999-1008.

[57] Machado, S., Humphreys, C., Tuck, B., and Corp, M. 2006.
Seeding date, plant density, and cultivar effects on chickpea yield and seed size in eastern Oregon. Online. Crop Management doi: 10.1094/CM-2006-0621-01-RS.

[58] Martin, J. H., W. H., Leonardo and O. L. Stamp. 1976. Principles of crop production. $3^{\text {rd }}$ ed. Macmillan publishing Co., Inc. New York.

[59] Matthews, P. W., E. L. Armstrong, C. J. Lisle, I. D. Menz, P. L. Shephard and B. C. Armstrong. 2008. The effect of faba bean plant population on yield, seed quality and plant architecture under irrigation in southern NSW. AustralianCrop Agronomy Journal, 40:23-25.

[60] Mehmet, O. Z., 2008. Nitrogen rate and plant population effects on yield and yield components in soybean. African Biotechnology Journal, 7(24): 4464-4470.

[61] Mekonnen, D. 1999. Effects of spacing and nitrogen fertilization on yield and related traits of finger millet [Eleusinecoracana (L.)Gaerth] growth on soils of Bako area, Western Ethiopia. M. Sc. Thesis, Alemaya University, Ethiopia.

[62] MenaleKassie, BekeleShiferaw, Solomon Asfaw, Tsedeke Abate, Geoffrey Muricho, SetotawFerede, Million Eshete, and KebebewAssefa. 2009. Current Situation and Future outlooks of the Chickpea Sub sector in Ethiopia. International Crops Research Institute for the Semi Arid Tropics (ICRISAT), Nairobi, and Ethiopian Institute of Agricultural Research (EIAR), DeberZeitAgricultral Research Centre, DebreZeit, Ethiopia. pp 1- 43.

[63] Metson A. J. 1961. Method of chemical analysis for soil survey samples. New Zealand DSIR Soil Bur Bull 12. Govt. printer, Wellington, New Zealand

[64] Miller W. R. and Roy L. Donahue. 1997. Soils in our environment. 7th ed. Prentice-Hall of India, New Delhi.

[65] Million Eshete.1994. Chickpea and Lentil Agronomy Research. In Cool season food and forage legumes of Ethiopia: PrCeedings of the National Cool-season Food and Forage Legumes Review Conference, 16-20 December 1993, Addis Ababa, Ethiopia (Tilaye A, Bejiga G, Saxena MC and SolhMd B, eds.). Aleppo, Syria: ICARDA; and Addis Ababa, Ethiopia: Ethiopian Agricultural Research Organization.

[66] Million Eshete. 1995. Chickpea (Cicerarietinum) and lentil (Lens culinaris) agronomy research. First National Coolseason Food Legumes Review Conference. Addis Ababa, Ethiopia, 16-20 Dec 1993, published in ICARDA, Aleppo (Syria).

[67] MoARD (Ministry of Agriculture and Rural Development). 2010. Crop Variety Register Issue No. 13, Animal and Plant Health regulatory directorate, Addis Ababa, Ethiopia.

[68] MoARD (Ministry of Agriculture and Rural Development). 2003. Plan for improving the productivity and marketing of chickpeas (Amharic). MoARD, Extension Department, Addis Ababa, Ethiopia. (mimeo). 52 pp.

[69] Oad, F. C., M. A. Samo, S. M. Qayylan and N. L. Oad. 2002. Inter and intra row spacing effect on the growth, seed yield and oil continent of safflower. Asian Plant ScienceJournal, 1: 18-19.

[70] Olsen, S. R., and L. A. Dean. 1965. Phosphorus. In: Methods of Soil Analysis. American SCiety of Agronomy, 9: 920-926. 
[71] Onwueme I. C., and T. D., Sinha. 1991. Field crop production in Tropical Africa, Principles and practice, CTA (Technical center for agriculture and rural cooperation) The Netherlands.

[72] Ouattara, S. and D. B. Weaver. 1994. Effect of growth habit on yield and agronomic characteristics of late-planted soybean. Crop Science, 34: 870- 873.

[73] Page, A. L. 1982. Methods of soil analysis. Part II. Chemical and Microbiological Properties. Madison. USA.

[74] Panwar, K. S., A. S. Faroda, D. S. Malik, L. P. S. Ahhawat, K. K. Dhingra, M. R. Rao, R. C. Singh, D. R. Dahiya, Singh, Atar and R. P. Roy Sharma, 1980. Response of chickpea varieties to seed rates and row spacings. Silver Jubilee SCiety of Agronomy. 9:54-55

[75] Parihar, S. S. 1996. The effect of row and plant spacings on the growth and yield of chickpea. Indian Journal of Agronomy 41(4):604-607.

[76] Parvez, A. Q. Gardner, F. P. and K. J. Boote. 1989. Determinate and indeterminate type soybean cultivar responses to pattern, density and planting date. Crop Science, 29:150-157

[77] Pilbeam, C. J., P. D. Hebblethwaite, H. E. Ricketts and T. E. Nyongesa. 1991. Effects of plant population density on determinate and indeterminate forms of winter faba beans (Viciafaba L.), I: yield and yield components, Agriculture ScienceJournal, 116: 375-383.

[78] Pundir, R. P. S. and H. M. Mengesha, 1983. Collection of chickpea in Ethiopia. Inter. Chickpea Newsletter, 8: 6-7.

[79] Rajesh, K., Yadav, B. D., John, R. K. and R. Kumar. 1997. The effect of inter and intra-row spacings and variety on the seed yield of cowpea. Tropical Agriculture, 15: 233-236.

[80] Ranist, V. E., M. Verloo, A. Demyer and J. M. Pawels, 1999. Manual for soil chemistry and fertility laboratory. Belgium, $\mathrm{p}$ 245.

[81] Rechinger, K. H. 1952. Arkiv for Botanik, StCkholm, AndraSerie 1: 510.

[82] RezeneFessehaie. 1994. Weed research in cool-season food legumes. In: PrCeedings of the First National Cool Food Season Legumes Review Conference, 16-20 December. 1993. Addis Ababa, Ethiopia. ICARDA/ Institute of Agricultural Research. ICARDA:Aleppo, Syria. pp: 252-278.

[83] Saxena, M. C. and K. B. Singh. 1987. The chickpea. CAB International, The international Center for Agricultural Research in the Dry Areas. Aleppo Syria.

[84] Shahein, A. H, E. M. R Agwah and H. A. El-Shamma. 1995. Effect of plan density as well as nitrogen and phosphorus fertilizer rate on growth green pods and dry seed yield and quantity of broad bean. Moshtohor Annual Agricultural Science, 33(1): 371-88.

[85] Shamsi, K. and S. Kobraee. 2009. Effect of plant density on the growth, yield and yield components of three soybean varieties under climatic conditions of Kermanshah, Iran. Animal and Plant Sciences Journal, 2(2): 96 - 99.

[86] Shamsi, K. 2005. Effect of sowing date and row spacing on yield and yield components of chickpea under rain fed conditions in Iran. Islamic Azad University, Kermanshah Branch, Iran. Published at
www.biosciences.elewa.org.Accessed on May 8, 2012

[87] Sharar MS, Ayub M, Nadeem MA, Noori SA. 2001. Effect of different row spacings and seeding densities on the growth and yield of gram (CicerarietinumL.). Department of Agronomy, University of Agriculture, Faisalabad, Pakistan. Pakistan Journal of Agricultural Science, 38: 51-53.

[88] Singh N. P, and R. A. Singh. 2002. Scientific crop production, $\mathrm{X}$ press Graphics, Delhi-28, $1^{\text {st }}$ ed., India

[89] Solomon Abate. 2003. Effects of irrigation frequency and plant population density on growth, yield components and yield of haricot bean (Phaseolus vulgaris L.) in Dire Dawa Area. M. Sc. Thesis Presented to Haramaya University, Ethiopia.

[90] Tanner, J. W.; and D. J. Hume. 1978. Management and Production. In: A. G. Norman (ed.)Soybean Physiology Agronomy and Utilization. Academic Press, New York. pp. 157-217.

[91] Togay N, Togay Y, Erman M, Yusuf D, Cig F. 2005. The effects of different plant densities on yield and yield components in some chickpea (CicerarietinumL.) cultivars in dry and irrigated conditions. Journal of Agricultural Science, 11(4): 417-421.

[92] Trang, K. M. and J. Giddens. 1980. Shading and temperature as environmental factors affecting growth, nodulation and symbiotic nitrogen fixation by Soybeans. Agronomy Journal, 72: 305-308.

[93] Tuba Biçer, B. 2008. The effect of seed size on yield and yield components of chickpea and lentil. African Journal of biotechnology, 8: 1482-1487.

[94] Turk, M. A, A. M. Tawaha and M. K. J. El-shatnawi. 2003. Response of lentil (Lens CulinarisMedk) to plant density, sowing date, phosphorus fertilization and ethephon application in the absence of moisture stress. Agriculture Crop Science Journal, 189: 1-6.

[95] Turk, M. A. and A. M. Tawaha. 2002. Impact of seeding rate, seeding date, rate and method of phosphorus application in faba bean (Viciafaba L. minor) in the absence of moisture stress. Biotechnology and Agronomy SCiety Environment, 6 (3): 171-178.

[96] Van der Maesen, L. J. G. 1972. CicerL. A monograph of the genus with special reference to a chickpea (CicerarietinumL.), its ecology and cultivation. Communication of the Agricultural Universitry, Wageningen 72: 10.

[97] Willey, R. W. 1982. Plant population and crop yield. In: MiloslavRechigl, Jr. (Ed.) Hand Book of Agricultural Productivity. CRC Press, Inc. BCa Raton, Florida. pp. 201207.

[98] Wilson, V. E. and I. D. Teare. 1972. Effects of spacing on lentil yield. Crop Science, 12: 507-510.

[99] Yousaf Ali, M. AhsanulHaq, G. R. Tahir, N. Ahimed. 1999. Effect of Intra and inter row spacing on the Yield and Yield components of chickpea. Pakistan Journal of Biological Science, 2(2):305-307.

[100] M. Shiferaw, T. Tamado and F. Asnake. 2018. Effect of Plant Density on Yield Components and Yield of Kabuli Chickpea (Cicerarietinum L.) Varieties at DebreZeit, Central Ethiopia. International Journal of Plant \& Soil Science 21(6). 
[101] R. P. Soratto, T. A. Catuchi, E. D. De Souza, J. L. Garcia. 2017. Plant Density and Nitrogen Fertilization on Common Bean Nutrition and Yield. Rev. Caatinga, Mossoró, V. 30, N. 3, P. $670-678$.
[102] M. Tuarira and M. Moses. 2014. Effects of Plant Density and Planting Arrangement in Green Bean Seed Production. Journal of Global Innovative Agriculture and SC. Sciences 2(4): 152-157. 